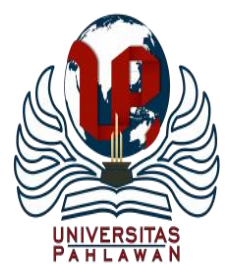

Edukatif : Jurnal Ilmu Pendidikan Volume 3 Nomor 3 Tahun 2021 Halm 847 - 853

EDUKATIF: JURNAL ILMU PENDIDIKAN

Research \& Learning in Education

https:/ledukatif.org/index.php/edukatif/index

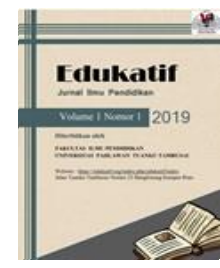

\title{
Konseling Individu Menggunakan Teknik Modeling untuk Meningkatkan Kedisiplinan Belajar Siswa
}

\author{
Geandra Ferdiansa ${ }^{1 凶}$, Yeni Karneli ${ }^{2}$ \\ Universitas Negeri Padang, Indonesia ${ }^{1,2}$ \\ E-mail: geandraferdiansa1995@ gmail.com ${ }^{1}$, yenikarneli.unp@ gmail.com ${ }^{2}$
}

\begin{abstract}
Abstrak
Disiplin belajar yang dimaksud dalam penelitian ini adalah terlambat masuk sekolah, bolos sekolah, tidak mengerjakan tugas dan terlambat masuk sekolah setelah jam istirahat. Tujuan penelitian ini adalah agar siswa mampu mengentaskan masalahnya secara mandiri dan meningkatnya kedisiplinan belajar siswa di sekolah setelah diberikan perlakuan konseling individu menggunakan teknik modeling. Penelitian ini menggunakan metode penelitian tindakan dengan sasaran siswa yang memiliki kasus kurang disiplin dalam belajar, penelitian ini dilaksanakan selama 1 bulan dan dilaksanakan dalam 2 siklus, penelitian ini dirancang berdasarkan penelitian tindakan yaitu: 1) perencanaan, 2). tindakan, 3). observasi dan 4). refleksi. Setelah diberikan perlakuan konseling individu menggunakan teknik modeling selama 1 bulan dalam 2 siklus, Hasil temuan penelitian pada siklus 1 menunjukkan bahwa konseling individu menggunakan teknik modeling yang diberikan belum efektif untuk meningkatkan kedisiplinan belajar siswa, setelah siklus ke 2 klien mampu mengentaskan masalahnya secara mandiri dan mampu disiplin dalam belajar. Berdasarkan hasil temuan penelitian maka konseling individu menggunakan teknik modeling efektif meningkatkan kedisiplinan belajar siswa.
\end{abstract}

Kata Kunci: Konseling individu, teknik modeling, disiplin belajar.

\section{Abstract}

The learning discipline referred to in this study is being late for school, skipping school, not doing assignments and being late for school after recess. The purpose of this research is that students are able to alleviate their problems independently and increase their learning discipline in schools after being given individual counseling treatment using modeling techniques. This research uses action research methods targeting students who have cases of lack of discipline in learning, this research was conducted for 1 month and carried out in 2 cycles, this study was designed based on action research, namely: 1) planning, 2). action, 3). observation and 4). reflection. After being given individual counseling treatment using modeling techniques for 1 month in 2 cycles, the findings of the study in cycle 1 showed that individual counseling using the given modeling technique was not yet effective in improving student learning discipline, after the second cycle the client was able to alleviate the problem independently and was able to discipline in learning. Based on the research findings, individual counseling using modeling techniques effectively improves student learning discipline.

Keywords: Individual counseling, modeling techniques, learning discipline.

Copyright (c) 2021 Geandra Ferdiansa, Yeni Karneli

$\triangle$ Corresponding author

Email : geandraferdiansa1995@gmail.com

DOI : https://doi.org/10.31004/edukatif.v3i3.427

ISSN 2656-8063 (Media Cetak)

ISSN 2656-8071 (Media Online)

Edukatif : Jurnal Ilmu Pendidikan Vol 3 No 3 Tahun 2021

p-ISSN 2656-8063 e-ISSN 2656-8071 
848 Konseling Individu Menggunakan Teknik Modeling untuk Meningkatkan Kedisiplinan Belajar SiswaGeandra Ferdiansa, Yeni Karneli

DOI: https://doi.org/10.31004/edukatif.v3i3.427

\section{PENDAHULUAN}

Berbicara mengenai masalah pendidikan di indonesia salah satu aspeknya adalah kedisiplinan belajar, rendahnya kedisiplinan belajar siswa berdampak pada kegiatan belajar siswa bahkan akan berdampak pada hasil belajar siswa, pelanggaran kedisiplinan belajar yang terjadi adalah telat masuk sekolah, tidak membuat tugas dan membolos, sejalan dengan pernyataan tersebut menurut Eka Setiawati (2015) kedisiplinan belajar merupakan sikap (perilaku) yang harus dimiliki oleh siswa. Siswa diharapkan dapat memperoleh hasil belajar yang memuaskan apabila siswa mampu mengatur waktu dan kegiatan belajarnya. Kusumawati et al (2017) jika siswa memiliki kedisiplinan dalam belajar, maka mereka akan selalu termotivasi untuk belajar. Lain halnya dengan siswa yang tidak disiplin dalam belajar, biasanya akan lambat dalam menangkap materi pelajaran yang diajarkan dan tidak termotivasi untuk belajar, bahkan sering malas untuk belajar. Tanpa adanya kedisiplinan belajar, dapat membuat siswa menghadapi kesulitan belajar. Hal itu akan berdampak pula pada hasil belajarnya. Dengan demikian, kedisiplinan belajar dapat berpengaruh terhadap hasil belajar siswa. Sedangkan Prasojo (2016) kedisiplinan belajar adalah kadar atau derajat kepatuhan peserta didik terhadap peraturan-peraturan dan tata tertib sekolah untuk memperoleh kondisi yang lebih baik dengan menjadikan disiplin sebagai control penguasan diri yang dilakukan tanpa adanya paksaan. Asim (2016) belajar dengan disiplin yang terarah dapat menghindarkan diri dari rasa malas dan menimbulkan kegairahan siswa dalam belajar, yang pada akhirnya akan dapat meningkatkan daya kemampuan belajar siswa. Disiplin adalah kunci sukses dan keberhasilan. Dengan disiplin seseorang menjadi yakin bahwa disiplin akan membawa manfaat yang dibuktikan dengan tindakannya.

Ada beberapa bentuk kedisiplinan siswa dalam belajar menurut Thornberg (2008) menjelaskan disiplin sekolah dapat digambarkan sebagai strategi yang dapat digunakan untuk mengkoordinasikan, mengatur dan mengorganisasikan siswa di sekolah. Disiplin siswa di sekolah terdiri dari beberapa bentuk indikatornya, yaitu: (1) disiplin siswa dalam masuk kelas, (2) disiplin siswa dalam mengerjakan tugas, (3) disiplin siswa dalam mengikuti pelajaran di kelas, dan (4) disiplin siswa dalam mentaati tata tertib di sekolah. Lebih lanjut Sobri \& Moerdiyanto (2014) konteks lingkungan sekolah, anak yang berdisiplin adalah anak yang taat terhadap tata tertib sekolah. Tata tertib sekolah tersebut meliputi: (1) mematuhi peraturan sekolah, (2) mengindahkan petunjuk-petunjuk berlaku di sekolah, (3) tidak berbohong, (4) berkelakuan baik, (5) mengerjakan tugas yang diberikan oleh guru, (6) tepat waktu masuk kelas sesuai jadwal pelajaran, (7) tidak meninggalkan kelas saat berlangsung proses belajar mengajar dan, (8) tidak membuat keributan dalam kelas supaya tidak menggangu konsentrasi saat proses belajar mengajar.

Kasus kedisiplinan belajar yang terjadi di MTs N 4 Kota Jambi seperti: Membuat keributan ketika guru tidak hadir dalam kelas, tidak segera masuk kedalam kelas ketika bel masuk berbunyi, ketika guru menjelaskan masih ada siswa yang tidak memperhatikan atau asik berbicara dengan temannya. Dan ketika wawancara dengan guru mata pelajaran matematika bahwasannya ketika guru memberikan tugas rumah ada beberapa siswa masih mengerjakan di sekolah, dan masih ada siswa yang tidak mengerjakan tugas. Mungkin dengan sikap belajar seperti ini prestasi belajar siswa akan rendah (Hidayat, 2020). Sedangkan kasus kedisiplinan belajar yang terjadi Madrasah Tsanawiyah Negeri 2 muaro jambi seperti 1). siswa masih lemah nya dalam kemampuan belajar sehingga cenderung tidak terkontrol prilakunya, 2), siswa kurang introspeksi diri dalam melaksanakan peraturan kelas, seperti ada siswa yang membawa handphone, sehingga anak kurang nyaman dalam berkonsentrasi belajar. Ada juga siswa yang merokok, disamping itu ada juga siswa yang membolos atau keluar masuk tanpa izin saat jam pelajaran berlangsung di sekolah, 3). masih 5 Fakultas Tarbiyah dan Keguruan lemah nya hukuman siswa, 4). randah nya dukungan dari orang tua dalam menyelesaikan masalah anak (Kumaini, 2013). 
849 Konseling Individu Menggunakan Teknik Modeling untuk Meningkatkan Kedisiplinan Belajar SiswaGeandra Ferdiansa, Yeni Karneli

DOI: https://doi.org/10.31004/edukatif.v3i3.427

Berdasarkan hasil observasi yang dilakukan oleh peneliti tanggal 15 November Tahun 2021 kasus kedisiplinan yang terjadi di salah satu SMPN Kerinci adalah siswa terlambat masuk sekolah, tidak membuat tugas yang diberikan oleh guru, sering membolos dan bahkan telat masuk kelas setelah jam pelajaran, perilaku kurang disiplin tersebut terjadi karena model yang diperhatikan oleh siswa selama ini tidak bagus atau juga berperilaku tidak disiplin. Berdasarkan permasalahan tersebut upaya yang dilakukan salah satunya adalah pemberian layanan konseling individual menggunakan teknik modeling untuk meningkatkan kedisiplinan belajar siswa. Prayitno (2004) konseling individual merupakan layanan konseling yang diselenggarakan oleh seorang konselor terhadap seorang konseli dalam rangka pengentasan masalah pribadi konseli. Dalam suasana tatap muka dilaksanakan interaksi langsung antara konseli dan konselor membahas berbagai hal tentang masalah yang dialami konseli.

Individual atau juga disebut layanan konseling individual dengan dinamika BMB3. Konseling Individual adalah salah satu layanan dalam bimbingan konseling yang diselenggarakan dalam rangka mengentaskan permasalahan-permasalahan yang dialami oleh konseli (Abdi \& Karneli, 2020). Biasanya selama proses konseling perorangan pembahasan masalah yang sedang dihadapi oleh klien dalam rangka pengentasan masalah pribadi klien, adanya konseling perorangan maka pikiran, perasaan dan sikap menjadi semakin terarah (Muthohharoh \& Karneli, 2020).

Salah satu satu teknik yang dapat digunakan untuk meningkatkan kedisiplinan belajar siswa adalah teknik modeling, Ma'mur Asmani (2010) teknik modeling merupakan teknik yang digunakan untuk membentuk perilaku baru pada klien dan memperkuat perilaku yang sudah terbentuk. Sedangkan hasil penelitian yang dilakukan oleh Arinata et al (2017) keberhasilan teknik modeling adalah dapat membantu siswa menghilangkan pikiran dan perilaku yang merugikan diri sendiri dan orang lain kemudian menggantinya dengan perilaku positif. Pengukuhan positif dapat memberikan penguatan dan rasa senang terhadap siswa atas apa yang sudah dilakukannya. Adapun langkah-langkah modeling menurut Bandura \& McClelland (2019) sebagai berikut. 1). Proses atensi (proses perhatian/attention processes): proses perhatian adalah saat seseorang memperhatikan sebuah kejadian atau perilaku. Perhatian ini dipengaruhi oleh ikatan dan perhatian pengamat pada modelnya, sifat model yang menyenangkan dan daya tarik mempunyai arti penting bagi tingkah laku yang diamati bagi si pengamat. 2). Proses retensi (proses peringatan/retention process): Proses mengingat (retensi) adalah kemampuan mengingat ketika seseorang telah mengamati model dan perilakunya. 3). Proses reproduksi motorik (motoric reproduction processes): proses reproduksi motorik merupakan kegiatan yang menirukan kembali apa saja yang telah diingat. 4). Proses penguatan dan motivasi (reinforcement and motivational processes): belajar melalui pengamatan menjadi efektif kalau peserta didik memiliki motivasi yang tinggi untuk mengamati tingkah laku model.

Berdasarkan beberapa kasus kedisiplinan belajar siswa dan beberapa pendapat para ahli, maka peneliti ingin mengangkat judul "Konseling Individu Menggunakan Teknik Modeling untuk Meningkatkan Kedisiplinan Belajar Siswa", judul ini dipilih untuk membantu mengentaskan permasalahan siswa yaitu kedisiplinan belajar, sehingga klien/siswa mampu mengentaskan permasalahan kedisiplinan belajarnya secara mandiri.

\section{METODE}

Penelitian ini menggunakan metode penelitian tindakan (action reseach) dalam setting bimbingan konseling. Sasaran dalam penelitian ini adalah salah seorang siswa SMPN 27 di Kabupaten Kerinci, subjek penelitian dipilih berdasarkan kehadiran siswa dan rekomendasi guru BK. Penelitian tindakan bimbingan konseling ini dilaksanakan selama 1 bulan agar pelaksanaan konseling individu menggunakan teknik modeling terlaksanakan secara maksimal dan dapat meningkatkan kedisiplinan siswa di sekolah. Penelitian ini dirancang berdasarkan penelitian tindakan yaitu: 1) perencanaan, 2). tindakan, 3). observasi dan 4). refleksi. Penelitian tindakan bimbingan konseling ini dilaksanakan dalam 2 siklus, siklus ke 2 diperlukan agar adanya 
850 Konseling Individu Menggunakan Teknik Modeling untuk Meningkatkan Kedisiplinan Belajar SiswaGeandra Ferdiansa, Yeni Karneli

DOI: https://doi.org/10.31004/edukatif.v3i3.427

peningkatan kedisiplinan belajar siswa setelah diberikan konseling individu menggunakan teknik modeling. Metode pengumpulan data kedisiplinan belajar siswa dalam penelitian ini adalah 1) observasi, 2) wawancara dan 3) kehadiran siswa di sekolah.

\section{HASIL DAN PEMBAHASAN}

Pada saat melaksanakan layanan, peneliti membuat rencana layanan konseling individu mengunakan teknik modeling, tujuannya agar konselor memiliki pedoman dalam melaksanakan layanannya. Materi yang disampaikan adalah cara meningkatkan kedisiplinan belajar. Siklus I dilaksanakan pada tanggal 16 November 2020. Alokasi waktu layanan memiliki durasi 2x40 menit per pertemuan dan dilaksanakan di ruang kelas VIII. Pelaksanaan layanan konseling individu menggunakan 5 tahapan yaitu: pengantaran, penjajakan, penafsiran, pembinaan dan penilaian. walaupun konseling individu menggunakan 5 tahapan akan tetapi tidak melupakan tahapan teknik modeling yaitu: perhatian, mengingat, reproduksi dan motivasi. model yang digunakan dalam konseling individu menggunakan teknik modeling ini adalah modeling simbolik (video), model yang ditampilkan pada klien diharapkan akan meningkatkan kedisiplinan siswa di sekolah dan siswa memahami bagaimana dampak kalau tidak disiplin dalam belajar.

Peneliti mengamati bagaimana pelaksanaan konseling individu menggunakan teknik modeling dan penilaian proses pelaksanaannya, peneliti melihat bahwa dinamika didalam proses pelaksanaan layanan konseling individu menggunakan teknik modeling masih belum efektif dan belum menemukan dinamika dalam pelaksanaan konseling individu menggunakan teknik modeling, klien kurang aktif dalam menanyakan mengenai permasalahan yang sedang ia alami dan juga video yang ditampilkan belum menarik bagi klien sehingga klien belum sepenuhnya tertarik dengan pelaksanaan teknik modeling ini. Metode yang digunakan dalam tahap refleksi ini adalah observasi, wawancara dan melihat perkembangan kehadiran siswa di sekolah. a). berdasarkan observasi, setelah klien mendapatkan perlakuan berupa layanan konseling individu menggunakan teknik modeling, peneliti melihat klien masih belum disiplin dalam belajar, akan tetapi intensitasnya tidak sesering sebelum diberikan konseling individu menggunakan teknik modeling. b). wawancara, peneliti mewawancarai guru BK dan wali kelas klien berpendapat bahwa klien masih terpengaruh oleh teman klien di sekolah, sehingga klien masih belum disiplin dalam belajar walaupun intensitasnya tidak sesering sebelum diberikannya konseling individu mengguakan teknik modeling, menurut Sugiarto et al (2019) ada beberapa faktor siswa belum disiplin dalam belajar yaitu orang tua yang kurang memberikan dukungan, guru yang kurang memerikan motivasi kepada siswa, teman sebaya atau lingkungan yang sangat mempengaruhi kedisiplinan siswa. Peran guru BK yang kurang memberikan motivasi belajar kepada siswa dengan memberikan layanan bimbingan konseling. c). berdasarkan kehadiran siwa di sekolah, peneliti melihat klien telah sering datang tepat waktu di pagi hari, akan tetapi masih telat masuk kelas setelah jam istirahat.

Ada beberapa faktor konseling individu kurang efektif dalam pelaksanaannya yaitu 1). Klien atau siswa adalah pribadi yang sangat penting dalam hubungan konseling, dimana semua aktifitas yang diselenggarakan didalamnya semata-mata ditujukan kepada peningkatan dirinya. Dengan demikian, segala sesuatu aktifitas yang bertujuan untuk kepentingan konselor tidaklah dapat disebut sebagai suatu konseling, 2).Kemampuan konselor melaksanakan konseling, 3).Sarana dan prasarana juga ikut serta mempengaruhi efektivitas pelaksanaan konseling individu terutama ruangan konseling, 4). waktu pelaksanaan konseling individu yang terbatas sehingga pelaksanaan konseling individu juga terbatas (Ramaini, 2012).

Pada tahap perencanaan siklus ke II konselor mempersiapkan konseling individu menggunakan teknik modeling, konselor mempersiapkan video yang menarik bagi siswa, tujuannya agar pelaksanaan konseling individu menggunakan teknik modeling terlaksanan secara efektif dan dapat membantu klien mengentaskan permasalahannya secara mandiri. Materi yang disampaikan adalah cara meningkatkan kedisiplinan belajar. 
851 Konseling Individu Menggunakan Teknik Modeling untuk Meningkatkan Kedisiplinan Belajar SiswaGeandra Ferdiansa, Yeni Karneli

DOI: https://doi.org/10.31004/edukatif.v3i3.427

Siklus II dilaksanakan pada tanggal 24 November 2020. Alokasi waktu layanan memiliki durasi 2 x40 menit per pertemuan dan dilaksanakan di ruang kelas VIII.

Pelaksanaan layanan konseling individu menggunakan 5 tahapan yaitu: pengantaran, penjajakan, penafsiran, pembinaan dan penilaian. walaupun konseling individu menggunakan 5 tahapan akan tetapi tidak melupakan tahapan teknik modeling yaitu: perhatian, mengingat, reproduksi dan motivasi. model yang digunakan dalam konseling individu menggunakan teknik modeling ini adalah modeling simbolik (video), model yang ditampilkan pada klien diharapkan akan meningkatkan kedisiplinan siswa di sekolah dan siswa memahami bagaimana dampak kalau tidak disiplin dalam belajar. pada tahap tindakan ini klien lebih efektif menangapi konselor dikarenakan klien tertarik dengan model (video) yang ditayangkan oleh konselor

Peneliti mengamati bagaimana pelaksanaan konseling individu menggunakan teknik modeling dan penilaian proses pelaksanaannya, peneliti melihat bahwa dinamika didalam proses pelaksanaan layanan konseling individu menggunakan teknik modeling lebih efektif dibandingkan siklus I dan juga dinamika dalam pelaksanaan konseling individu menggunakan teknik modeling lebih baik dibandingkan sebelumnya, klien aktif menanggapi dan juga klien tertarik pada model (video) yang ditayangkan, sehingga klien berkomitmen untuk tidak mengulangi kembali perilakunya yang terdahulu yaitu: sering telat masuk kelas, tidak mengerjakan tugas yang diberikan oleh guru mata pelajaran, sering telat masuk kelas setelah jam istirahat dan tidak lagi bolos sekolah, klien juga akan meningkatkan kedisiplinannya dalam belajar.

Metode yang digunakan dalam tahap refleksi ini adalah observasi, wawancara dan melihat perkembangan kehadiran siswa di sekolah. a). berdasarkan observasi, setelah klien mendapatkan perlakuan berupa layanan konseling individu menggunakan teknik modeling, peneliti mengamati klien selama 3 minggu terlihat klien telah mulai mematuhi peraturan sekolah, datang sekolah tepat waktu, tidak bolos sekolah dan mengerjakan tugas yang diberikan oleh guru mata pelajaran. b). wawancara, peneliti mewawancarai guru BK dan wali kelas berpendapat bahwa klien telai mulai disiplin dalam belajar tidak seperti sebelumnya. c). berdasarkan kehadiran siwa di sekolah, peneliti mengamati klien selama 3 minggu terlihat klien mulai disiplin dalam belajar, tidak bolos sekolah, datang sekolah tepat waktu dan mengerjakan tugas yang diberikan oleh guru mata pelajaran.

Berdasarkan temuan penelitian di atas, dapat disimpulkan bahwa adanya perubahan klien sebelum diberikan perlakuan konseling individu menggunakan teknik modeling dan setelah diberikan konseling individu menggunakan teknik modeling, konseling individu lebih efektif dan berdinamika menggunakan teknik modeling sehingga mampu meningkatkan kedisiplinan belajar siswa di sekolah, salah satu penyebabnya adalah model (video) yang ditayangkan oleh konselor menarik bagi siswa, siswa merasa menyesal tidak disiplin dalam belajar dan siswa berkomitmen akan meningkatkan disiplin dalam belajar. Adiputra (2015) pembelajaran melalui observasi paling efektif terjadi apabila pihak yang belajar termotivasi untuk melakukan prilaku yang ditiru. Perhatian dan representasi dapat berakibat pada pengumpulan informasi untuk belajar, namun pertama difasilitasi oleh motivasi untuk melakukan prilaku tertentu. Ada beberapa efek konseling individual menggunakan teknik modeling pada perilaku siswa adalah a) siswa belajar hal baru melalui pengamatan yaitu tayangan video, b) melalui pengamatan terhadap tokoh, siswa terdorong untuk melakukan sesuatu yang mungkin sudah diketahui atau dipelajari dan tidak ada hambatan. c) hilangnya respon takut setelah melihat tokoh melakukan sesuatu yang menimbulkan rasa takut, d) siswa menerapkan perilaku baru dan menghilangkan perilaku agresif di dalam kehidupannya sehari-hari (Saputra, 2018).

\section{KESIMPULAN}

Berdasarkan hasil temuan di atas dapat disimpulkan bahwa adanya perubahan perilaku siswa sebelum diberikan perlakuan dan setelah diberikan perlakukan, sebelum diberikan perlakuan konseling individual menggunakan teknik modeling, siswa sering telat masuk kelas, membolos dan tidak mengerjakan tugas. setelah perlakuan diberikan yaitu konseling individual menggunakan teknik modeling siswa termotivasi 
852 Konseling Individu Menggunakan Teknik Modeling untuk Meningkatkan Kedisiplinan Belajar SiswaGeandra Ferdiansa, Yeni Karneli

DOI: https://doi.org/10.31004/edukatif.v3i3.427

dengan model yang ditampilkan oleh konselor, sehingga siswa berkomitmen tidak akan mengulangi perbuatannya kembali yaitu telat masuk sekolah, membolos, tidak mengerjakan tugas dan akan lebih disiplin dalam belajar.

\section{DAFTAR PUSTAKA}

Abdi, S., \& Karneli, Y. (2020). Kecanduan Game Online: Penanganannya dalam Konseling Individual. Guidance, 17(02), 9-20.

Adiputra, S. (2015). Penggunaan Teknik Modeling Terhadap Perencanaan Karir. Jurnal Fokus Konseling, l(1).

Arinata, F. S., Sugiyo, \& Purwanto, E. (2017). Keefektifan Bimbingan Kelompok Teknik Modeling dan Pengukuhan Positif untuk Mengurangi Perilaku Bullying Siswa SD. Jurnal Bimbingan Konseling, 6(2), 154-158.

Asim, T. M. (2016). Pengaruh Bimbingan Manajemen Diri dalam Meningkatkan Kedisiplinan Belajar Siswa. Journal of Educational Science and Technology (EST), 2(2), 105.

Bandura, A., \& McClelland, D. C. (2019). Social learning: Theory. In Encyclopedia of Animal Behavior (pp. 380-386).

Eka Setiawati. (2015). Pengaruh Pola Asuh Terhadap Kedisiplinan Belajar Siswa Eka. 1(1), 27-34.

Hidayat, R. N. (2020). Pengaruh Kedisiplinan Belajar Terhadap Prestasi Belajar Matematika Siswa Madrasah Tsanawiyah Negeri 4 Kota Jambi. Journal of Chemical Information and Modeling, 21(1), 1-9.

Kumaini, A. (2013). Strategi Guru Akidah Akhlak dalam Meningkatkan Kedisiplinan Belajar Siswa di Madrasah Tsanawiyah Negeri2 Kabupaten Muaro Jambi. In Journal of Chemical Information and Modeling (Vol. 53, Issue 9).

Kusumawati, O. D. T., Wahyudin, A., \& Subagyo. (2017). Pengaruh Pola Asuh , Lingkungan Masyarakat dan Kedisiplinan Belajar Terhadap Hasil Belajar Siswa SD Kecamatan Bandungan. Educational Management, 6(2), 87-94.

Ma'mur Asmani, J. (2010). Panduan efektif bimbingan dan konseling di sekolah. Jogjakarta:Diva Press.

Muthohharoh, M., \& Karneli, Y. (2020). Layanan Konseling Perorangan Dengan Teknik Kursi Kosong untuk Meningkatkan Keterampilan Komunikasi Interpersonal. Guidance, 17(01), 14-19.

Prasojo, R. J. (2016). Pengaruh perhatian orang tua dan kedisiplinan siswa terhadap prestasi belajar mata pelajaran IPS. Jurnal Penelitian Dan Pendidikan IPS, 9(2), 1131-1149.

Prayitno, E. A. (2004). Dasar-dasar bimbingan dan konseling. Jakarta:PT. Rineka Cipta.

Ramaini, L. (2012). Efektifitas Layanan Konseling Individual Mengatasi Kenakalan Siswa Kelas Xi Di Sekolah Menengah Atas Negeri 12 Pekanbaru. (Doctoral Dissertation, Universitas Islam Negeri Sultan Syarif Kasim Riau)., 32.

Saputra. (2018). Efektivitas Bimbingan Kelompok Dengan Teknik Modelling Untuk Mengembangkan Kemampuan Interaksi Sosial Peserta Didik Kelas viii di SMP Negeri 9 Bandar Lampung Tahun Ajaran 2017/2018. Director, 15(40), 6-13.

Sobri, M., \& Moerdiyanto, M. (2014). Pengaruh Kedisiplinan Dan Kemandirian Belajar Terhadap Hasil Belajar Ekonomi Madrasah Aliyah Di Kecamatan Praya. Harmoni Sosial: Jurnal Pendidikan IPS, 1(1), $43-56$.

Sugiarto, A. P., Suyati, T., \& Yulianti, P. D. (2019). Faktor Kedisiplinan Belajar Pada Siswa Kelas X Smk Larenda Brebes. Mimbar Ilmu, 24(2), 232. 
853 Konseling Individu Menggunakan Teknik Modeling untuk Meningkatkan Kedisiplinan Belajar Siswa Geandra Ferdiansa, Yeni Karneli DOI: https://doi.org/10.31004/edukatif.v3i3.427

Thornberg, R. (2008). School Children's Reasoning About School Rules. Research Papers in Education, 23(1), 37-52. 